\title{
Table of Contents
}

Introduction

Daniela Carpi

Shakespeare and the Law: State of the Art - 3

François Ost

As You Law It...: Of Certain Objects and Functions of Ambiguity in Shakespearean Theatre -15

Part One The Body Politic and Power Politics

Daniela Carpi

King John or the Proliferation of the Word of Authority -27

Chiara Battisti

Richard the Freak: The Dis-ability to Show Power - 39

Sidia Fiorato

Performance, Power, Politics: The Body as Stage in Richard III - 63

Gilad Ben-Nun

The Subjugation of International Law to Power Politics and Mystery of State (Arcana Imperii) in Shakespeare's Henry $V-87$

Part Two Ethnicity and Alterity

Heinz Antor

Ethnicity, Alterity and the Law in Shakespeare's The Merchant of Venice - 107

Paul Raffield

Shakespeare's Twin Brother: Foreigners, Outlaws, and The Comedy of Errors - 131 
VI - Table of Contents

\section{Part Three Legal Theory}

Jeanne Gaakeer

Fuss about a Footnote, or the Struggle for (the) Law in German Legal

Theory 155

François Ost

Measure for Measure: Are Criminal Laws Made to Be Applied? — 183

Filippo Sgubbi

Measure in Penal Law 199

Carlo Pelloso

Are the Conspirators Purgers or Murderers? Shakespeare's Julius Caesar and Roman Ius Sacrum 203

\section{Part Four Performance}

Gary Watt

Notes on A Strange Eventful History - 227

Marett Leiboff

"Stir Up the Australian Youth to Merriment": A Midsummer Night's Dream, Summer 1989-1990 (Sydney, Australia) and the Theatrical Transmutability of Law's Texts -247

Contributors -269

Index of Names -273

Subjext Index -275 